\title{
Renal cancer biomarkers: the promise of personalized care
}

Naveen S Vasudev ${ }^{1 *}$, Peter J Selby ${ }^{2}$ and Rosamonde E Banks ${ }^{2}$

\begin{abstract}
Significant advances in our understanding of the biology of renal cell carcinoma (RCC) have been achieved in recent years. These insights have led to the introduction of novel targeted therapies, revolutionising the management of patients with advanced disease. Nevertheless, there are still no biomarkers in routine clinical use in RCC. Tools used routinely to determine prognosis have not changed over the past decade; classification remains largely morphology based; and patients continue to be exposed to potentially toxic therapy with no indication of the likelihood of response. Thus the need for biomarkers in RCC is urgent. Here, we focus on recent advances in our understanding of the genetics and epigenetics of RCC, and the potential for such knowledge to provide novel markers and therapeutic targets. We highlight on-going research that is likely to deliver further candidate markers as well as generating large, well-annotated sample banks that will facilitate future studies. It is imperative that promising candidates are validated using these resources, and in subsequent prospective clinical trials, so that future biomarkers may be used in the clinic to personalize patient care.
\end{abstract}

Keywords: Biomarkers, epigenomics, genomics, renal cell carcinoma, transcriptomics

\section{Renal cell carcinoma}

Renal cancer is the eighth most common cancer in the UK. There are over 270,000 new cases worldwide each year, 9,000 of which occur in the UK [1,2]. It accounts for more than 100,000 deaths across the world per annum [2]. The vast majority (approximately 90\%) of renal cancers arise in the renal parenchyma and are

\footnotetext{
* Correspondence: N.Vasudev@leeds.ac.uk

${ }^{1}$ The Institute of Cancer Research, Fulham Road, London SW3 6JB, UK Full list of author information is available at the end of the article
}

termed renal cell carcinomas (RCC). The incidence of $\mathrm{RCC}$ has been steadily rising over the past 20 years in many countries and this is thought to be only partially explained by the increased rate of incidental diagnosis.

The most common histological subtype of RCC is the conventional or clear cell (ccRCC) type accounting for $70 \%$ to $80 \%$ of cases. Central to the biology of ccRCCs, which form the focus of this review, is loss of function of the Von Hippel-Lindau (VHL) tumour suppressor gene (TSG), located on chromosome 3p. More than $90 \%$ of sporadic ccRCCs have $V H L$ involvement, almost defining this subgroup of tumours [3,4]. Loss of function of the VHL protein leads to stabilisation of hypoxia-inducible factors, nuclear transcription factors that in turn can activate the transcription of many genes including those encoding vascular endothelial growth factor (VEGF) and platelet derived growth factor.

The majority (60\% to $70 \%$ ) of patients present with localised disease, for which radical or partial nephrectomy remains the standard of care and is largely curative. However, approximately one third of these patients will subsequently relapse and die of their disease. Accurately determining the risk of relapse after nephrectomy is a key issue for patients and clinicians. This would not only inform and personalize imaging and follow-up schedules but also determine the risk:benefit ratio for adjuvant therapy, if on-going trials are positive. Current nomograms used to determine risk are still based on clinicopathological criteria only, and were developed more than a decade ago [5]. Such scoring systems are reasonably accurate at a population level but distinguishing risk for individuals, particularly those deemed at intermediate risk, remains poor. This is a key area where biomarkers are urgently required in RCC.

Insights into the biology of ccRCC have directly led to the recent introduction of a number of effective systemic therapies (see Figure 1). Antiangiogenic VEGF receptor (VEGFR)-targeted tyrosine kinase inhibitors (TKI), such as sunitinib and pazopanib, are established as front-line therapy for patients with advanced RCC. However, the clinical
C Biomed Central

() 2012 Vasudev et al; licensee BioMed Central Ltd. This is an Open Access article distributed under the terms of the Creative Commons Attribution License (http://creativecommons.org/licenses/by/2.0), which permits unrestricted use, distribution, and reproduction in any medium, provided the original work is properly cited. 


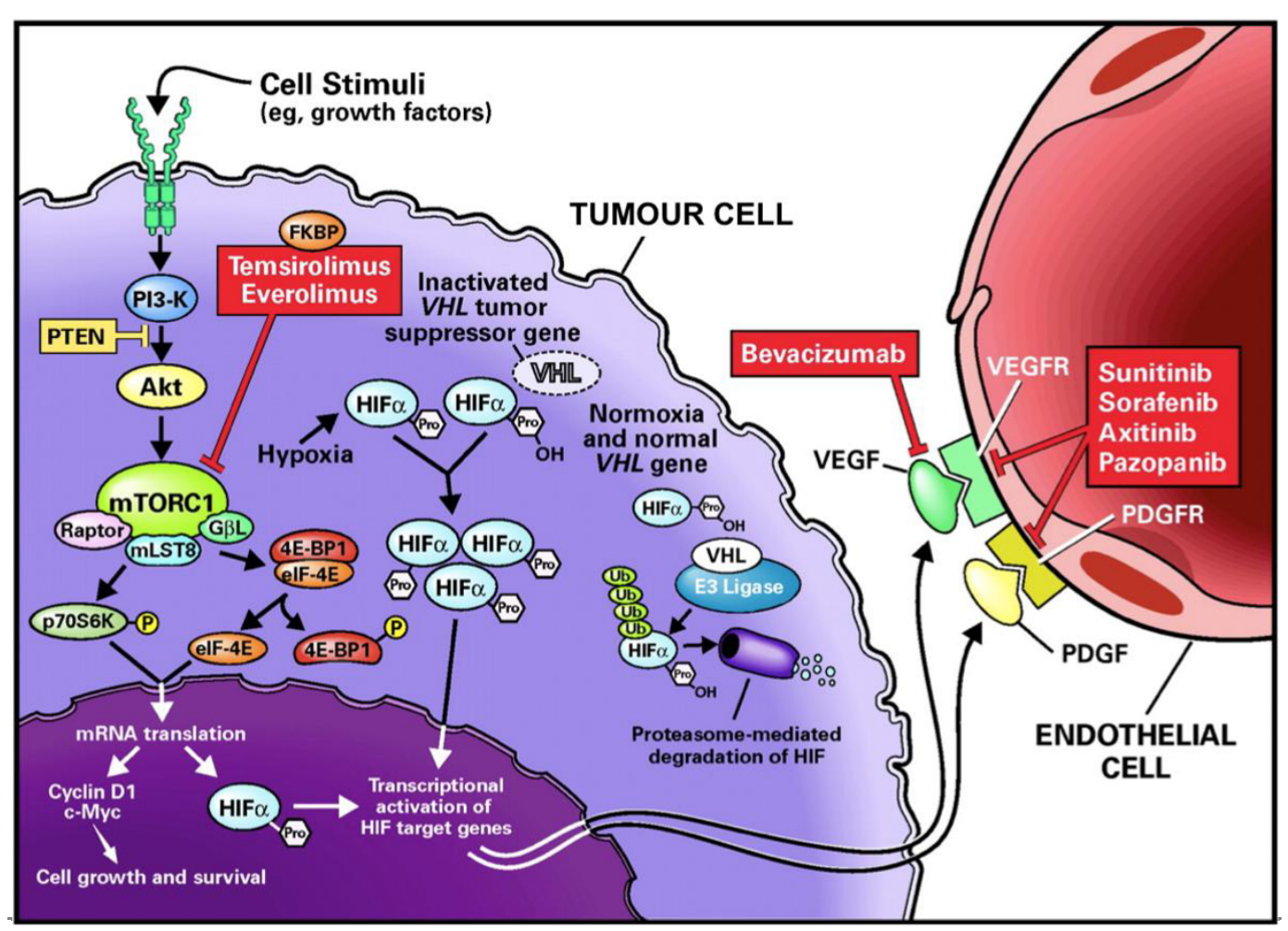

Figure 1 Biological pathways targeted for therapy in renal cell carcinoma based on a knowledge of the underlying genetic changes and downstream biological consequences. Loss of function of the VHL tumour suppressor gene leads to stabilisation of hypoxia-inducible factor alpha $(H I F \alpha)$. Activated HIF translocates into the nucleus and leads to the transcription of a large number of hypoxia-inducible genes including vascular endothelial growth factor (VEGF) and platelet derived growth factor (PDGF). Mammalian target of rapamycin (mTOR) is a kinase within the PI3K Akt pathway that can promote cell growth and survival pathways as well as causing accumulation of HIF. Bevacizumab is a monoclonal antibody to VEGF whilst sunitinib, sorafenib, axitinib and pazopanib are VEGF receptor tyrosine kinase inhibitors. These agents are thought to primarily function as antiangiogenic agents, inhibiting ligand binding or downstream receptor signalling of VEGF and PDGF on endothelial cells. Temsirolimus and everolimus inhibit the kinase activity of the mTOR complex 1 (mTORC1). Reproduced with permission from Elsevier@. From [66]. HIF: hypoxia-inducible factor; mTOR: mammalian target of rapamycin; mTORC1: mTOR complex 1; PDGF: platelet derived growth factor; PTEN: phosphatase and tensin homolog; VEGF: vascular endothelial growth factor; VEGFR: vascular endothelial growth factor receptor.

benefit an individual patient will derive from such therapy is highly variable and largely unpredictable. Between $20 \%$ and $30 \%$ of patients with ccRCC derive no benefit from first-line TKI treatment [6,7]. In addition, these drugs are toxic and expensive. Modern medical practice demands value for money. There is thus great impetus to discover biomarkers in RCC that can identify the subpopulation of patients destined to gain maximal benefit from any given drug. Numerous studies, variably examining clinicopathological criteria, VHL status, serum cytokines and angiogenic factors in relation to TKI response have been published, and reviewed elsewhere [8].

Despite the tremendous spectrum of behaviour that characterises ccRCCs, the current approach to the management of patients with these tumours remains largely generic. Robust and clinically validated biomarkers are required if the long-held promise of personalized medicine is to be realised. In this review, we summarise some of the most recent and promising areas of genetic and epigenetic biomarker research in ccRCC. We also highlight a number of large biomarker initiatives in RCC that are underway and, finally, we discuss some of the issues related to successfully bringing RCC biomarkers into the clinic. A detailed review of protein biomarkers of RCC and the potential of proteomics strategies in this area is beyond the scope of the current review and has been covered elsewhere by the authors [9]. In addition, although the current focus is on ccRCC, much greater research is also urgently required into the other, less common, subtypes of RCC, to define the biology of these tumours and lead to rational therapeutic design.

\section{Recent advances in genetic, epigenetic and transcriptomic understanding of clear cell renal cell carcinoma}

Tremendous progress has been made in recent years in terms of our understanding of the genetic basis of cancer. In particular, the advent of second-generation DNA 
sequencing technology is allowing researchers to start to systematically catalogue the thousands of somatic mutations that can typically be found in adult cancers and it is expected that tens of thousands of cancer genomes will be sequenced in the next 5 years [10]. This is, therefore, a time of great anticipation and it is expected that studies at genetic, epigenetic and transcriptomic levels will together identify the full complement of key driver mutations and epigenetic contributions across all cancer types, including RCC [11]. Complemented by information obtained at the level of the proteome [12], it is expected that these studies will together ultimately result in the identification of novel biomarkers and therapeutic targets of cancer.

\section{DNA}

Amongst the most notable genetic abnormalities associated with ccRCCs are loss of chromosome 3p (70\% to $80 \%)$ and gain of chromosome $5 q$ (50\% to $60 \%)$ [13]. Loss-of-function mutations in the remaining VHL allele are thought to represent an early event in ccRCC development but are not sufficient alone to drive tumour growth. A second major TSG recently implicated in ccRCC is the SW1/SNF chromatin remodelling complex gene polybromo1 (PBRM1), with truncating mutations found in $41 \%$ of the 227 cases tested [14]. Other genes, such as SET domain containing protein 2 and Jumonji $A T$-rich interactive domain $1 C$ have also been implicated, although at much lower frequency (3\%) [15]. More recently, mutations in $B R C A$ related protein-1 (BAP1) have been reported, with inactivation of BAP1 protein in $15 \%$ of ccRCCs. Interestingly, mutations in PBRM1 and BAP1 were largely observed to occur exclusively, suggesting that simultaneous loss may be disadvantageous to the tumour [16]. In comparison with the PBRM1 mutation, BAP1-deficient tumours were of higher grade and had distinct gene expression profiles. Distinguishing these genetically distinct subgroups may, therefore, have important prognostic and therapeutic implications for individual patients. It is of note that this may be achievable at the protein level, examining BAP1 protein expression by immunohistochemistry, for example, which is less expensive, has a higher throughput and is more routinely available [16].

The real message from these studies is perhaps that even relatively large-scale analyses may be underpowered to capture the full spectrum of mutations that drive these tumours and must be differentiated from the many bystanders. There is, therefore, a need for even larger studies, ultimately including thousands, rather than hundreds, of samples and covering whole genomes so that potentially important non-exomic changes can also be identified. Such studies are in fact underway (see later) and are required if further significant insights, beyond VHL, PBRM1 and BAP1, are to be gained.

\section{Gene expression microarrays}

Gene expression microarrays represent a promising method by which to subclassify tumours, both across subtypes and within clear cell carcinomas. Importantly, of course, they encompass both upstream genetic and epigenetic changes. Such approaches may also provide prognostic information that can be implemented in daily clinical practice. A proof of concept has been established in other tumour types, such as breast cancer: MammaPrint is a Food and Drug Administration approved 70gene signature, stratifying tumours as high or low risk, which has been widely adopted into clinical practice in countries such as the USA. Studies to date in ccRCC have established that these tumours can also be stratified based on gene expression profiling, and that this may provide information independent of stage and grade [17-20]. However, these studies have typically been small, with limited numbers of genes analysed, and not independently validated. Indeed, in a recently published meta-analysis of gene-expression studies in ccRCC, just six studies were included after excluding those with fewer than 20 tumours, those with fewer than 5,000 genes analysed, those containing no clinical data and redundant publications of previous data [21]. The meta-array assembled gene expression data from 480 tumours, encompassing 6,386 genes. Based on previous work by the same authors, the study demonstrated the ability of such profiling to segregate ccRCCs into two distinct subtypes, termed ccA and ccB. ccA tumours relatively overexpressed genes associated with hypoxia, angiogenesis and fatty acid metabolism and carried a favourable prognosis in comparison with $\mathrm{ccB}$ tumours, which overexpressed a more aggressive panel of genes associated with epithelial-mesenchymal transition, cell cycle and wound healing. Interestingly, rates of VHL involvement were similar between the two groups [18]. A third, small (14\%) cluster of tumours could also be identified, $82 \%$ of which were classed as VHL wild-type. Importantly, a histological review of these cases demonstrated that over half displayed deviations from classical clear cell features, suggesting that such tumours may warrant distinct classification.

Another recent study combined copy number analysis with gene expression analysis to identify potential novel subtypes and therapeutic targets in ccRCC. The study examined 54 cases of sporadic ccRCC, and found 350 concordantly gained and overexpressed genes. Gain in chromosome $5 \mathrm{q}$ was observed in $30 \%$ of cases, and stanniocalcin (STC2) and versican (VCAN) were identified as potential oncogenes in ccRCCs, which appear to act by 
inhibiting cell death [22]. The study is notable for describing gain-of-function aberrations, rather than the more commonly described loss of function in tumour suppressors; these gain-of-function aberrations may represent more direct therapeutic targets

Histopathological classification of RCC can prove challenging in some cases $[23,24]$. The ability to differentiate between subtypes is important, because prognosis and treatment can vary, and there are implications for clinical trial recruitment. Gene expression signatures, using as few as 10 genes, have shown more than $90 \%$ accuracy in distinguishing between clear cell, papillary and chromophobe RCCs as well as benign oncocytomas [25]. Such profiling may prove to be of value in the clinic if shown to have the ability to subtype currently unclassifiable tumours, or in cases that are otherwise difficult to distinguish (for example, eosinophilic tumours). In addition, the increasing interest in neoadjuvant therapy means that pathologists are required to make initial diagnoses on much more limited amounts of tissue, derived from core biopsies alone, where expression profiling may also prove useful.

\section{Single nucleotide polymorphisms}

Large genome-wide association studies have recently reported SNPs that may increase the risk of an individual developing RCC [26,27]. Such genetic variation within our germline, in addition to somatic mutations within tumours, may also help to explain observed differences in response and toxicity to anticancer agents.

A number of SNP-based studies in RCC addressing the response to TKI therapy have recently been published. In the largest study of 397 patients treated with pazopanib, 27 polymorphisms amongst 13 genes, including those related to angiogenesis (VEGFA/IL-8/fibroblast growth factor 2), metabolism (cytochrome $P_{450}$ (CYP) $3 \mathrm{~A} 4 / 5)\})$ and transport (ATP-binding cassette (ABC) B1) were evaluated. Two IL- 8 polymorphisms, linked to increased gene expression, were associated with a significantly shorter median PFS (27 weeks) than those carrying the wild-type genotype (48 weeks) $(P=0.01)$ [28]. It is of note that IL- 8 has recently been identified as a potential driver of resistance to TKIs [29], making the results of biological relevance. A second study, conducted prospectively, examined both response $(\mathrm{n}=89)$ and toxicity $(\mathrm{n}=95)$ to sunitinib in patients with ccRCC. A total of 16 polymorphisms were examined in nine genes. Two VEGFR3 missense polymorphisms were associated with reduced PFS and a high metabolising variant of CYP3A $5 * 1$ was associated with increased toxicity on multivariable analysis. However, the reported SNPs involving IL-8 were not demonstrated in this study [30]. In a retrospective study of 136 patients with metastatic ccRCC treated with sunitinib, 30 SNPs in 11 genes were examined, and correlated with PFS. Survival was significantly improved in relation to SNPs in $C Y P 3 A 5$, ligand-activated nuclear receptor $N R 1 I 3$ and $A B C B 1$, but not in VEGFR3 [31].

Thus, studies to date in this area show little concordance. The frequency of the reported SNPs in the tested populations was typically low, highlighting the need for such studies to be much larger to increase their power to detect significant differences. Furthermore, the applicability of the results to populations of differing ethnicity is also unknown.

\section{DNA methylation}

DNA methylation represents the best characterised mechanism by which cancer cells can epigenetically regulate gene expression. Methylation of cytosine residues within CpG dinucleotides can alter the transcription rate of a given gene and bring about transcriptional silencing. Cancer cells often demonstrate TSG inactivation as a result of aberrant promoter hypermethylation [32].

In sporadic ccRCC, the VHL TSG is inactivated via methylation in approximately $10 \%$ to $30 \%$ of cases $[3,4,33]$. Methylation studies, including recent genomewide based approaches, have now identified a large number of other candidate TSGs inactivated by hypermethylation in ccRCC, which, in many cases, occur at high frequency within the studied sample sets [34,35]. The Ras association domain family 1 gene, for example, codes for a protein that functions as a negative regulator of the cell cycle and is methylated in approximately $45 \%$ of cases [33]. Secreted frizzled related protein 1, which antagonises Wnt signalling, is methylated in 34\% to $68 \%$ of ccRCC tumours [36,37]. Many other examples exist, as recently reviewed [38].

Such studies clearly provide further insights into the biology of ccRCC but can markers of methylation also serve as novel biomarkers in the clinic? Correlations between methylation status and patient outcome have been reported although none have been validated. Methylation of gremlin1, a protein that antagonises growth factor signalling, has been correlated with a poorer overall survival in patients with ccRCC. The study included 185 patients, $40 \%$ of whom had methylation of the gremlin1 gene [39]. Methylation of GATAbinding protein 5 has recently been correlated with the development of metastasis $(P=0.005)$ and decreased progression-free survival $(P=0.005$, hazard ratio $=4.59)$ in 84 patients with ccRCC [40]. In another study of 69 patients with ccRCC, in the $19 \%$ of patients with methylation of signal peptide CUB EGF-like domain-containing protein 3 , risk of cancer death or relapse was significantly increased $(P=0.0046)$ [35].

Intriguing data have recently been published from studies in bladder cancer, another urological malignancy, 
suggesting that urinary methylation markers may be used to diagnose bladder cancer [41]. Furthermore, such markers may also predict the progression of early bladder lesions to muscle-invasive tumours with a high degree of accuracy [42]. It is also possible that urinary DNA methylation markers may be used in RCC to allow early detection of disease, potentially using a pan-urological panel of markers [43].

\section{microRNA}

miRNAs are single-stranded, non-coding RNAs approximately 22 nucleotides long that are emerging as a potentially important and novel source of epigenetic biomarkers in RCC. miRNAs function by regulating gene expression at a post-transcriptional level, binding to target mRNA, typically resulting in translational downregulation, inhibition and/or mRNA degradation but also, more rarely, upregulation. miRNAs are altered in many cancers, including RCC, and can affect many tumourigenic pathways including cell cycle regulation, proliferation, cell motility, metastasis, apoptosis and angiogenesis.

Many alterations in the expression of miRNAs in RCC have been described to date (for reviews see $[44,45]$ ) and provide fresh insight into the aetiology and biology of these tumours. miR210, for example, has consistently been reported to be upregulated in ccRCC in response to hypoxia, and promotes anaerobic respiration and cell cycle progression and inhibits pro-apoptotic signalling [46-48]. Furthermore, expression of miR210 has been correlated with a significantly poorer overall survival $(P$ $=0.0006)$, even among a small number of patients $(\mathrm{n}=$ 31) [49].

miRNA-based signatures may also allow for improved classification of tumour subtypes. In a recent study of 94 fresh frozen samples, composed of normal renal epithelium and clear cell, papillary and chromophobe RCC subtypes as well as oncocytomas, 91 miRNAs were found to be significantly differentially expressed. Clear cell tumours were shown to be more closely related to papillary RCC and both were distinct from chromophobe and oncocytomas, which were more closely related. Tumours could be classified using unique miRNA signatures in a maximum of four steps. The system had a sensitivity of 97\% in distinguishing normal from RCC, 100\% for clear cell RCC, $97 \%$ for papillary subtype and 100\% accuracy in distinguishing oncocytoma from chromophobe tumours. This latter distinction is notoriously difficult based on morphology alone [50].

It is worth noting that miRNAs are stable and can in fact be reliably measured in formalin-fixed paraffinembedded material. Furthermore, as recent studies have shown, miRNAs can also be measured in serum and serve as potential diagnostic markers of disease [51,52].
Finally, and perhaps most exciting, miRNAs may serve as novel therapeutic targets. Because any given miRNA may target hundreds to thousands of genes, such an approach may have the capacity to 'hit' several pathways simultaneously. However, at present, such an approach remains in its infancy across all cancer types, not just in RCC.

\section{Current renal cell carcinoma biomarker initiatives}

A number of large-scale biomarker initiatives are underway in RCC, some of which are described below.

\section{CAGEKID}

The Cancer Genomics of the Kidney (CAGEKID) consortium [53], funded by the European Union (EU) (total $€ 10$ million), aims to carry out comprehensive genetic, epigenetic and transcriptomic analysis in ccRCC. Extensive characterisation of 100 patients and two phases of targeted validation in a further 400 and 2,300 patients will be performed. The study forms part of the International Cancer Genome Consortium initiative [11] and, as such, all samples entered are subject to pathology panel review and minimum standards used in terms of viable tumour cell number. The consortium is composed of 14 partners from 6 EU countries (plus Russia), including the Czech Republic. A schema for the CAGEKID study is shown in Figure 2. The study is currently in its initial validation phase.

\section{Evaluation of biomarkers in patients with renal cell carcinoma}

As part of a National Institute for Health Research funded programme ('Biomarker pipeline'), tissue and fluid samples from patients with RCC are being collected at 10 UK centres, with a target of 600 patients at baseline, longitudinal sampling in a further 200 patients and long-term follow-up in all. Samples are being collected according to strict standard operating procedures, together with clinical data via case report forms. An important remit of the study is the careful evaluation of existing and future putative prognostic and longitudinal monitoring protein biomarkers for use in the clinic, incorporating validation of developed and existing assays. The sample bank will also be available for future gene and protein studies [54].

\section{EuroTARGET}

EuroTARGET (TArgeted therapy in Renal cell cancer: GEnetic and Tumour related biomarkers for response and toxicity) is another European collaboration, composed of 12 partner organisations from 8 countries, funded by the European Commission under the Seventh Framework Programme. The aim of the study is to identify predictive biomarkers of response and toxicity to 


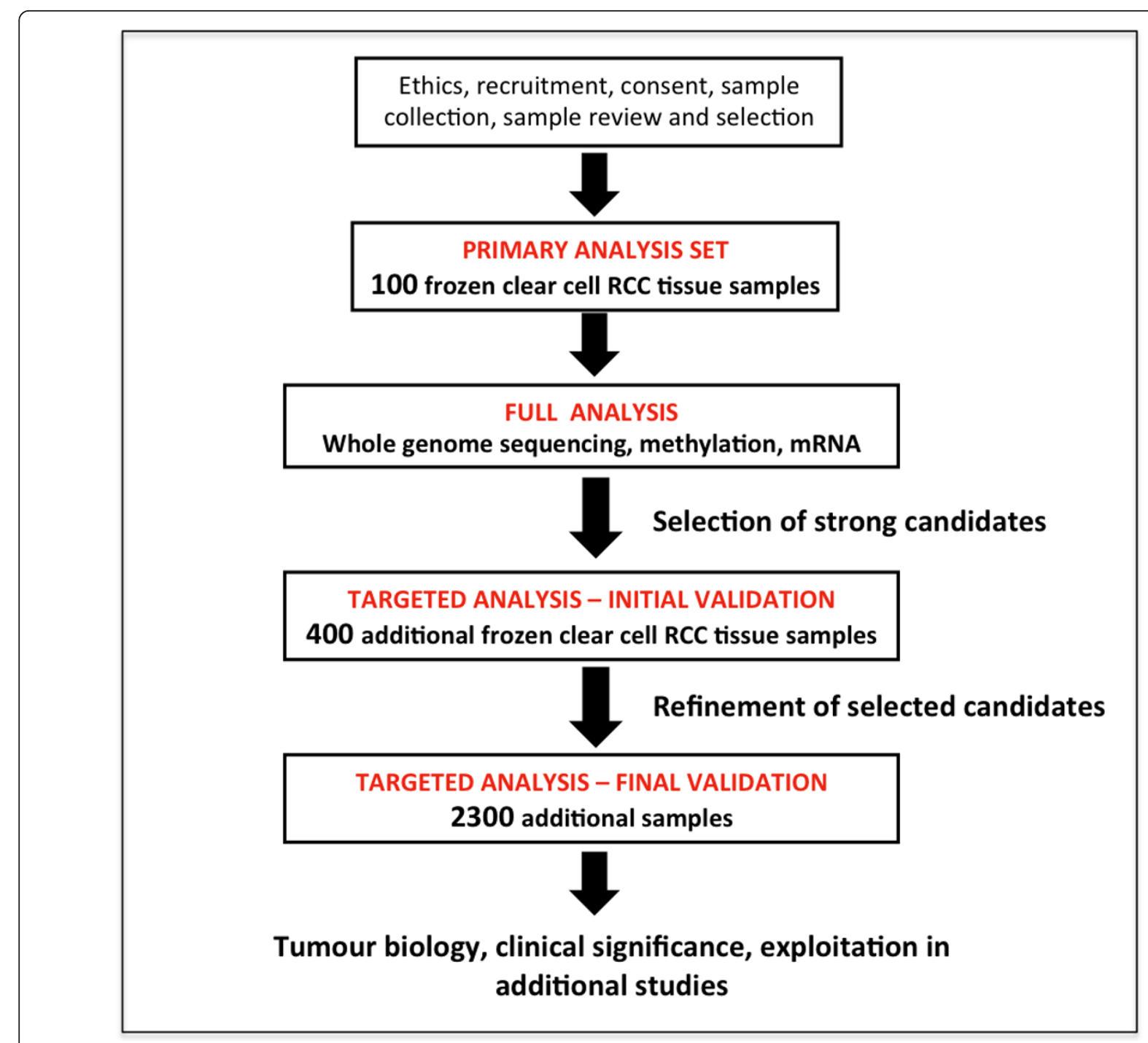

Figure 2 Cancer Genomics of the Kidney (CAGEKID) study schema. RCC: renal cell carcinoma.

targeted therapy in patients with RCC using approaches that include germline genome analysis and tumour gene expression and methylation studies [55].

\section{SCOTRRCC}

The Scottish Collaboration on Translational Research into RCC (SCOTRRCC) is a Scotland-wide initiative involving 10 centres, aimed at banking clinical samples from newly diagnosed patients with RCC to address various clinical and scientific research questions. Samples will be collected, processed and stored in a robust and uniform manner, accompanied by comprehensive clinical annotation, providing a further highly valuable biobank.

\section{PREDICT Consortium}

personalized RNA Interference to Enhance the Delivery of Individualised Cytotoxic and Targeted therapeutics
(PREDICT) is a European collaboration aimed at identifying predictive biomarkers of response to sunitinib and everolimus in patients with RCC [56]. Patients within the study provide consent to receive neoadjuvant therapy, allowing the collection and comparison of tissue both before and after exposure to the drug. Tumours will be comprehensively genomically profiled and highthroughput screens using short hairpin RNA and small interfering RNA will be used to identify and validate functionally important genomic or transcriptomic predictive biomarkers of individual drug response in patients.

\section{TCGA}

The Tumour Cancer Genome Atlas (TCGA) is a US initiative funded by the National Institutes of Health that sets out to comprehensively genomically profile 20 
different tumour types, including both ccRCC and papillary RCC. The study has already banked its target of 500 ccRCC samples, and aims to conduct whole genome sequencing in 50 of these cases. As with other initiatives, the data will be made available to the scientific community [57].

\section{The future of using biomarkers for personalized medicine for renal cancer}

Treatment options and outlook for patients with renal cancer have seen significant improvement in recent years: surgical techniques have improved; tumour-ablative procedures are more widely available; and effective targeted agents have been discovered. But what next? Further major advances are likely to require the introduction of biomarkers into clinical practice to personalize patient care.

An abundance of potential candidate RCC biomarkers exist in the literature, yet none have progressed beyond the discovery phase, an issue that has plagued biomarker research across all cancer types [58]. Some of the most promising markers in RCC are in fact proteins, such as B7-H1 and insulin-like growth factor II mRNA binding protein 3, that have been shown in RCC to have strong, independent prognostic ability, have been externally validated and add value to existing nomograms $[59,60]$, yet appear to have stalled at this point in the 'biomarker pipeline' (Figure 3). Even C-reactive protein, a more routine and easily measured marker, has not been evaluated further, despite having been shown in multiple studies to be of prognostic value and occur not just as an inflammatory marker but be produced by RCC cells [61]. If genomic markers are not to similarly stall in their development, it is important that these issues are urgently addressed. As others have argued [62], to date, too much emphasis has been placed on the discovery phase of biomarker research and not enough on validation and integration of markers into clinical care. Thus, alongside current discovery initiatives, a priority in RCC biomarker research must be to validate, in or out, existing promising markers, following robust assay development.

Can biomarkers be successfully integrated into clinical practice in RCC? It is certainly appealing to envisage a future in which patient management is influenced by molecular information that can be reliably provided in 'real-time'. Thus, from a single renal biopsy, a wealth of information would be gleaned at both a genetic and protein level, defining the tumour more so on its molecular profile than its site of origin. Based on this notion, initiatives such as Cancer Research UK's Stratified Medicines Programme are already exploring how the National Health Service can provide molecular profiling routinely for all cancer types and lay the foundations for a national service that can deliver standardised, high quality, cost-effective genetic testing of tumours [63].

Among the many issues relating to the successful introduction of individualised cancer care, perhaps one the greatest challenges comes from the increasing recognition that individual tumours, across many cancer types, are themselves highly heterogeneous [64]. The remarkable degree of heterogeneity that exists within individual ccRCCs has recently been elegantly demonstrated [65]. Using multi-region genetic analysis, this study showed that the majority (approximately two thirds) of mutations are not present in every region of a tumour, and that a single biopsy would capture only a minority of the genetic aberrations present. Furthermore, different areas of the same tumour variably returned either a favourable or unfavourable prognostic profile, using the gene expression array described above [18], suggesting possible diversity amongst biologically relevant (driver) mutations.

Such heterogeneity of course is a feature of all cancers and potentially carries significant implications for
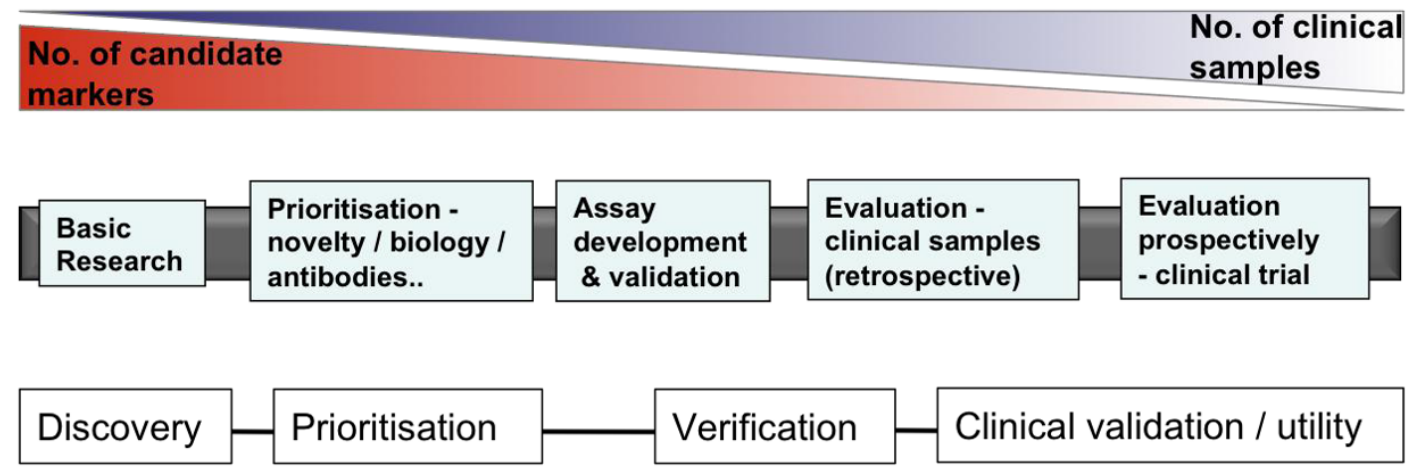

Figure 3 Biomarker pipeline. Biomarkers must be carefully evaluated along each phase of the pipeline for successful adoption into clinical practice. 
successful biomarker validation and the delivery of personalized care [64]. A single biopsy may not be representative of the tumour as a whole and even multiple sampling post-nephrectomy may be inadequate. A further level of complexity is also added by the fact that the signature of the primary tumour may not necessarily reflect that of distant metastatic deposits [65]. What remains uncertain, however, is the extent to which these differences actually impact on the tumour phenotype and, for instance, the expression of protein biomarkers and therapeutic targets. For now, the key message is that heterogeneity exists and must be considered along the route to successful biomarker validation.

\section{Conclusions}

This is a highly promising time in the field of RCC biomarker research. The advent of high-throughput molecular profiling technologies is leading to a revolution in our understanding of the biology and make-up of RCC and, in parallel, a number of large-scale, collaborative biomarker discovery initiatives are underway. It is expected that these studies, complemented by proteomic initiatives, will identify further novel candidate biomarkers of RCC. Equal efforts must then be applied to the clinical validation phase for such studies to be rendered worthwhile.

\section{Author information}

$\mathrm{NV}$ is a Medical Oncologist and Research Fellow at the Institute of Cancer Research, Royal Marsden Hospital, London. PS is Professor of Cancer Medicine at the St James's Institute of Oncology, University of Leeds and Director of the Leeds Institute of Molecular Medicine (LIMM). RB is Professor of Biomedical Proteomics, LIMM. RB and PS lead the Clinical and Biomedical Proteomics Group, focused on biomarker and therapeutic target discovery in renal cell carcinoma. The authors are partners within both the EU CAGEKID and the National Institute for Health Research biomarker evaluation programmes.

\footnotetext{
Abbreviations

ABC: ATP-binding cassette; BAP1: BRCA related protein-1; CAGEKID: Cancer Genomics of the Kidney consortium; ccRCC: clear cell renal cell carcinoma; CYP: cytochrome P450; EU: European Union: IL-8: interleukin 8; mRNA: messenger RNA; miRNA: microRNA; PFS: progression-free survival; PBRM1: polybromo1; RCC: renal cell carcinoma; SNP: single nucleotide polymorphism; TKI: tyrosine kinase inhibitor; TSG: tumour suppressor gene; VEGF: vascular endothelial growth factor; VEGFR: vascular endothelial growth factor receptor; VHL: Von Hippel-Lindau.

\section{Author details \\ ${ }^{1}$ The Institute of Cancer Research, Fulham Road, London SW3 6JB, UK. ${ }^{2}$ Cancer Research UK Centre, Leeds Institute of Molecular Medicine, St James's University Hospital, Leeds, UK.}

\section{Authors' contributions}

NV wrote the first draft of the manuscript, which RB and PS critically reviewed. All authors read and approved the final manuscript.

\section{Competing interests}

The authors declare that they have no competing interests.

Received: 29 May 2012 Accepted: 27 September 2012

Published: 27 September 2012

\section{References}

1. Cancer Research UK: Kidney cancer statistics. 2012 [http://info. cancerresearchuk.org/cancerstats/types/kidney].

2. Ferlay J, Shin HR, Bray F, Forman D, Mathers C, Parkin DM: GLOBOCAN 2008 v1.2, Cancer incidence and mortality worldwide in 2008. IARC CancerBase No. 10 [Internet] Lyon, France: International Agency for Research on Cancer; 2010 [http://globocan.iarc.fr/].

3. Young AC, Craven RA, Cohen D, Taylor C, Booth C, Harnden P, Cairns DA, Astuti D, Gregory W, Maher ER, Knowles MA, Joyce A, Selby PJ, Banks RE: Analysis of $\mathrm{VHL}$ gene alterations and their relationship to clinical parameters in sporadic conventional renal cell carcinoma. Clin Cancer Res 15:7582-7592.

4. Nickerson ML, Jaeger E, Shi Y, Durocher JA, Mahurkar S, Zaridze D, Matveev V, Janout V, Kollarova H, Bencko V, Navratilova M, SzeszeniaDabrowska N, Mates D, Mukeria A, Holcatova I, Schmidt LS, Toro JR, Karami S, Hung R, Gerard GF, Linehan WM, Merino M, Zbar B, Boffetta P, Brennan P, Rothman N, Chow WH, Waldman FM, Moore LE: Improved identification of von Hippel-Lindau gene alterations in clear cell renal tumors. Clin Cancer Res 2008, 14:4726-4734.

5. Sun M, Shariat SF, Cheng C, Ficarra V, Murai M, Oudard S, Pantuck AJ, Zigeuner R, Karakiewicz PI: Prognostic factors and predictive models in renal cell carcinoma: a contemporary review. Eur Urol 2011, 60:644-661.

6. Motzer RJ, Hutson TE, Tomczak P, Michaelson MD, Bukowski RM, Rixe O, Oudard S, Negrier S, Szczylik C, Kim ST, Chen I, Bycott PW, Baum CM, Figlin RA: Sunitinib versus interferon alfa in metastatic renal-cell carcinoma. N Engl J Med 2007, 356:115-124.

7. Sternberg CN, Davis ID, Mardiak J, Szczylik C, Lee E, Wagstaff J, Barrios CH, Salman P, Gladkov OA, Kavina A, Zarbá JJ, Chen M, McCann L, Pandite L, Roychowdhury DF, Hawkins RE: Pazopanib in locally advanced or metastatic renal cell carcinoma: results of a randomized phase III trial. $J$ Clin Oncol 2010, 28:1061-1068.

8. Eisengart LJ, MacVicar GR, Yang XJ: Predictors of response to targeted therapy in renal cell carcinoma. Arch Pathol Lab Med 2012, 136:490-495.

9. Vasudev NS, Banks RE: Biomarkers of renal cancer. In Biomarkers in Kidney Disease.. 1 edition. Edited by: Edelstein CL. London: Elsevier; 2011:313-344.

10. Stratton MR: Exploring the genomes of cancer cells: progress and promise. Science 2011, 331:1553-1558.

11. International Cancer Genome Consortium, Hudson TJ, Anderson W, Artez A Barker AD, Bell C, Bernabé RR, Bhan MK, Calvo F, Eerola I, Gerhard DS, Guttmacher A, Guyer M, Hemsley FM, Jennings JL, Kerr D, Klatt P, Kolar P, Kusada J, Lane DP, Laplace F, Youyong L, Nettekoven G, Ozenberger B, Peterson J, Rao TS, Remacle J, Schafer AJ, Shibata T, Stratton MR, et al: International network of cancer genome projects. Nature 2010, 464:993-998.

12. Boja $E$, Hiltke $T$, Rivers $R$, Kinsinger $C$, Rahbar A, Mesri M, Rodriguez $H$ : Evolution of clinical proteomics and its role in medicine. J Proteome Res 2011, 10:66-84

13. Teh BT, Farber $\sqcup$, Furge K: Molecular charactersation of renal cell carcinoma. In Renal cell carcinoma. Translational biology, personalized medicine, and novel therapeutic targets. Edited by: Figlin RA, Rathmell WK, Rini BI. New York: Springer; 2012:91-111.

14. Varela I, Tarpey P, Raine K, Huang D, Ong CK, Stephens P, Davies H, Jones D, Lin ML, Teague J, Bignell G, Butler A, Cho J, Dalgliesh GL, Galappaththige D, Greenman C, Hardy C, Jia M, Latimer C, Lau KW, Marshall J, McLaren S, Menzies A, Mudie L, Stebbings L, Largaespada DA, Wessels LF, Richard S, Kahnoski RJ, Anema J, et al: Exome sequencing identifies frequent mutation of the SWI/SNF complex gene PBRM1 in renal carcinoma. Nature 2011, 469:539-542.

15. Dalgliesh GL, Furge K, Greenman C, Chen L, Bignell G, Butler A, Davies H, Edkins S, Hardy C, Latimer C, Teague J, Andrews J, Barthorpe S, Beare D, Buck G, Campbell PJ, Forbes S, Jia M, Jones D, Knott H, Kok CY, Lau KW, Leroy C, Lin ML, McBride DJ, Maddison M, Maguire S, McLay K, Menzies A, Mironenko $T$, et al: Systematic sequencing of renal carcinoma reveals inactivation of histone modifying genes. Nature 2010, 463:360-363. 
16. Peña-Llopis S, Vega-Rubín-de-Celis S, Liao A, Leng N, Pavía-Jiménez A, Wang S, Yamasaki T, Zhrebker L, Sivanand S, Spence P, Kinch L, Hambuch T, Jain S, Lotan Y, Margulis V, Sagalowsky Al, Summerour PB, Kabbani W, Wong SW, Grishin N, Laurent M, Xie XJ, Haudenschild CD, Ross MT, Bentley DR, Kapur P, Brugarolas J: BAP1 loss defines a new class of renal cell carcinoma. Nat Genet 2012, 44:751-759.

17. Sanjmyatav J, Steiner T, Wunderlich H, Diegmann J, Gajda M, Junker K: A specific gene expression signature characterizes metastatic potential in clear cell renal cell carcinoma. J Urol 2011, 186:289-294.

18. Brannon AR, Reddy A, Seiler M, Arreola A, Moore DT, Pruthi RS, Wallen EM, Nielsen ME, Liu H, Nathanson KL, Ljungberg B, Zhao H, Brooks JD, Ganesan S, Bhanot G, Rathmell WK: Molecular stratification of clear cell renal cell carcinoma by consensus clustering reveals distinct subtypes and survival patterns. Genes Cancer 2010, 1:152-163.

19. Zhao H, Ljungberg B, Grankvist K, Rasmuson T, Tibshirani R, Brooks JD: Gene expression profiling predicts survival in conventional renal cell carcinoma. PLoS Med 2006, 3:e13

20. Takahashi M, Rhodes DR, Furge KA, Kanayama H, Kagawa S, Haab BB, Teh BT: Gene expression profiling of clear cell renal cell carcinoma: gene identification and prognostic classification. Proc Natl Acad Sci USA 2001, 98:9754-9759

21. Brannon AR, Haake SM, Hacker KE, Pruthi RS, Wallen EM, Nielsen ME, Rathmell WK: Meta-analysis of clear cell renal cell carcinoma gene expression defines a variant subgroup and identifies gender influences on tumor biology. Eur Urol 2011, 61:258-268.

22. Dondeti VR, Wubbenhorst B, Lal P, Gordan JD, D'Andrea K, Attiyeh EF, Simon MC, Nathanson KL: Integrative genomic analyses of sporadic clear cell renal cell carcinoma define disease subtypes and potential new therapeutic targets. Cancer Res 2012, 72:112-121.

23. Valera VA, Merino MJ: Misdiagnosis of clear cell renal cell carcinoma. Nat Rev Urol 2011, 8:321-333

24. Reuter VE, Tickoo SK: Differential diagnosis of renal tumours with clear cell histology. Pathology 2010, 42:374-383.

25. Sanford $T$, Chung $P H$, Reinish $A$, Valera $V$, Srinivasan $R$, Linehan WM, Bratslavsky G: Molecular sub-classification of renal epithelial tumors using meta-analysis of gene expression microarrays. PLoS One 2011, 6:e21260.

26. Purdue MP, Johansson M, Zelenika D, Toro JR, Scelo G, Moore LE, Prokhortchouk E, Wu X, Kiemeney LA, Gaborieau V, Jacobs KB, Chow WH, Zaridze D, Matveev V, Lubinski J, Trubicka J, Szeszenia-Dabrowska N, Lissowska J, Rudnai P, Fabianova E, Bucur A, Bencko V, Foretova L, Janout V, Boffetta P, Colt JS, Davis FG, Schwartz KL, Banks RE, Selby PJ, et al: Genome-wide association study of renal cell carcinoma identifies two susceptibility loci on 2p21 and 11q13.3. Nat Genet 2011, 43:60-65.

27. Wu X, Scelo G, Purdue MP, Rothman N, Johansson M, Ye Y, Wang Z, Zelenika D, Moore LE, Wood CG, Prokhortchouk E, Gaborieau V, Jacobs KB, Chow WH, Toro JR, Zaridze D, Lin J, Lubinski J, Trubicka J, SzeszeniaDabrowska N, Lissowska J, Rudnai P, Fabianova E, Mates D, Jinga V, Bencko V, Slamova A, Holcatova I, Navratilova $M$, Janout $V$, et al: A genome-wide association study identifies a novel susceptibility locus for renal cell carcinoma on 12p11.23. Hum Mol Genet 2012, 21:456-462.

28. Xu CF, Bing NX, Ball HA, Rajagopalan D, Sternberg CN, Hutson TE, de Souza P, Xue ZG, McCann L, King KS, Ragone LJ, Whittaker JC, Spraggs CF, Cardon LR, Mooser VE, Pandite LN: Pazopanib efficacy in renal cell carcinoma: evidence for predictive genetic markers in angiogenesisrelated and exposure-related genes. J Clin Oncol 2011, 29:2557-2564.

29. Huang D, Ding Y, Zhou M, Rini BI, Petillo D, Qian CN, Kahnoski R, Futreal PA, Furge KA, Teh BT: Interleukin-8 mediates resistance to antiangiogenic agent sunitinib in renal cell carcinoma. Cancer Res 2010, 70:1063-1071

30. Garcia-Donas J, Esteban E, Leandro-Garcia LJ, Castellano DE, del Alba AG, Climent MA, Arranz JA, Gallardo E, Puente J, Bellmunt J, Mellado B, Martínez E, Moreno F, Font A, Robledo M, Rodríguez-Antona C: Single nucleotide polymorphism associations with response and toxic effects in patients with advanced renal-cell carcinoma treated with first-line sunitinib: a multicentre, observational, prospective study. Lancet Oncol 2011, 12:1143-1150.

31. van der Veldt AA, Eechoute K, Gelderblom H, Gietema J, Guchelaar HJ, van Erp NP, van den Eertwegh AJ, Haanen JB, Mathijssen RH, Wessels JA: Genetic polymorphisms associated with a prolonged progression-free survival in patients with metastatic renal cell cancer treated with sunitinib. Clin Cancer Res 2011, 17:620-629.
32. Jones PA, Baylin SB: The fundamental role of epigenetic events in cancer. Nat Rev Genet 2002, 3:415-428.

33. Dulaimi E, Ibanez de Caceres I, Uzzo RG, Al-Saleem T, Greenberg RE, Polascik TJ, Babb JS, Grizzle WE, Cairns P: Promoter hypermethylation profile of kidney cancer. Clin Cancer Res 2004, 10:3972-3979.

34. Ricketts CJ, Morris MR, Gentle D, Brown M, Wake N, Woodward ER, Clarke N, Latif F, Maher ER: Genome-wide CpG island methylation analysis implicates novel genes in the pathogenesis of renal cell carcinoma. Epigenetics 2012, 7:278-290.

35. Morris MR, Ricketts CJ, Gentle D, McRonald F, Carli N, Khalili H, Brown M, Kishida T, Yao M, Banks RE, Clarke N, Latif F, Maher ER: Genome-wide methylation analysis identifies epigenetically inactivated candidate tumour suppressor genes in renal cell carcinoma. Oncogene 2011, 30:1390-1401.

36. Dahl E, Wiesmann F, Woenckhaus M, Stoehr R, Wild PJ, Veeck J, Knuchel R, Klopocki E, Sauter G, Simon R, Wieland WF, Walter B, Denzinger S, Hartmann A, Hammerschmied CG: Frequent loss of SFRP1 expression in multiple human solid tumours: association with aberrant promoter methylation in renal cell carcinoma. Oncogene 2007, 26:5680-5691.

37. Morris MR, Ricketts C, Gentle D, Abdulrahman M, Clarke N, Brown M, Kishida T, Yao M, Latif F, Maher ER: Identification of candidate tumour suppressor genes frequently methylated in renal cell carcinoma. Oncogene 2010, 29:2104-2117.

38. Hoffman AM, Cairns P: Epigenetics of kidney cancer and bladder cancer Epigenomics 2011, 3:19-34.

39. van Vlodrop IJ, Baldewijns MM, Smits KM, Schouten $L$, van Neste L, van Criekinge W, van Poppel H, Lerut E, Schuebel KE, Ahuja N, Herman JG, de Bruïne AP, van Engeland M: Prognostic significance of Gremlin1 (GREM1) promoter CpG island hypermethylation in clear cell renal cell carcinoma. Am J Pathol 2010, 176:575-584.

40. Peters I, Eggers H, Atschekzei F, Hennenlotter J, Waalkes S, Tränkenschuh W Großhennig A, Merseburger AS, Stenzl A, Kuczyk MA, Serth J: GATA5 CpG island methylation in renal cell cancer: a potential biomarker for metastasis and disease progression. BJU Int 2012, 110(2 Pt B):E144-E152.

41. Reinert T, Modin C, Castano FM, Lamy P, Wojdacz TK, Hansen LL, Wiuf C, Borre M, Dyrskjot L, Orntoft TF: Comprehensive genome methylation analysis in bladder cancer: identification and validation of novel methylated genes and application of these as urinary tumor markers. Clin Cancer Res 2011, 17:5582-5592.

42. Kandimalla R, van Tilborg AA, Kompier LC, Stumpel DJ, Stam RW Bangma $\mathrm{CH}$, Zwarthoff EC: Genome-wide analysis of $\mathrm{CpG}$ island methylation in bladder cancer identified TBX2, TBX3, GATA2, and ZIC4 as pTa-specific prognostic markers. Eur Urol 2012, 61:1245-1256.

43. Costa $V L$, Henrique $R$, Danielsen SA, Eknaes M, Patricio P, Morais A, Oliveira J, Lothe RA, Teixeira MR, Lind GE, Jerónimo C: TCF21 and PCDH17 methylation: An innovative panel of biomarkers for a simultaneous detection of urological cancers. Epigenetics 2011, 6(9):1120-1130.

44. Redova M, Svoboda M, Slaby O: MicroRNAs and their target gene networks in renal cell carcinoma. Biochem Biophys Res Commun 2011, 405:153-156

45. Catto JW, Alcaraz A, Bjartell AS, De Vere White R, Evans CP, Fussel S, Hamdy FC, Kallioniemi O, Mengual L, Schlomm T, Visakorpi T: MicroRNA in prostate, bladder, and kidney cancer: a systematic review. Eur Urol 2011, 59:671-681.

46. Valera VA, Walter BA, Linehan WM, Merino MJ: Regulatory effects of microRNA-92 (miR-92) on VHL gene expression and the hypoxic activation of miR-210 in clear cell renal cell carcinoma. J Cancer 2011, 2:515-526.

47. Chen Z, Li Y, Zhang H, Huang P, Luthra R: Hypoxia-regulated microRNA210 modulates mitochondrial function and decreases ISCU and COX10 expression. Oncogene 2010, 29:4362-4368.

48. Juan D, Alexe G, Antes T, Liu H, Madabhushi A, Delisi C, Ganesan S, Bhanot G, Liou LS: Identification of a microRNA panel for clear-cell kidney cancer. Urology 2010, 75:835-841.

49. Neal CS, Michael MZ, Rawlings LH, Van der Hoek MB, Gleadle JM: The VHLdependent regulation of microRNAs in renal cancer. BMC Med 2010, 8:64.

50. Youssef YM, White NM, Grigull J, Krizova A, Samy C, Mejia-Guerrero S, Evans A, Yousef GM: Accurate molecular classification of kidney cancer subtypes using microRNA signature. Eur Urol 2011, 59:721-730.

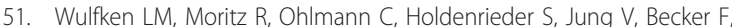
Herrmann E, Walgenbach-Brunagel G, von Ruecker A, Müller SC, Ellinger J: 
MicroRNAs in renal cell carcinoma: diagnostic implications of serum miR-1233 levels. PLoS One 2011, 6:e25787.

52. Redova M, Poprach A, Nekvindova J, lliev R, Radova L, Lakomy R, Svoboda M, Vyzula R, Slaby O: Circulating miR-378 and miR-451 in serum are potential biomarkers for renal cell carcinoma. J Transl Med 2012, 10:55.

53. CAGEKID. [http://www.cng.fr/cagekid/index.html].

54. Biomarker pipeline. [http://www.biomarkerpipeline.org/nihr/].

55. EuroTARGET. [http://www.eurotargetproject.eu/].

56. PREDICT consortium. [http://www.predictconsortium.eu/].

57. TCGA. [http://cancergenome.nih.gov/].

58. Poste G: Bring on the biomarkers. Nature 2011, 469:156-157.

59. Hoffmann NE, Sheinin Y, Lohse CM, Parker AS, Leibovich BC, Jiang Z, Kwon ED: External validation of IMP3 expression as an independent prognostic marker for metastatic progression and death for patients with clear cell renal cell carcinoma. Cancer 2008, 112:1471-1479.

60. Thompson RH, Kuntz SM, Leibovich BC, Dong H, Lohse CM, Webster WS, Sengupta S, Frank I, Parker AS, Zincke H, Blute ML, Sebo TJ, Cheville JC, Kwon ED: Tumor B7-H1 is associated with poor prognosis in renal cell carcinoma patients with long-term follow-up. Cancer Res 2006, 66:3381-3385.

61. Saito K, Kihara K: Role of C-reactive protein as a biomarker for renal cell carcinoma. Expert Rev Anticancer Ther 2011, 10:1979-1989.

62. Lotan Y: The challenges of harnessing new technology. Eur Urol 2012, 61:269-270.

63. Cancer Research UK: Stratified medicine programme. [http://science. cancerresearchuk.org/research/how-we-deliver-our-research/others/byprogramme/stratified-medicine-programme/].

64. Marusyk A, Almendro V, Polyak K: Intra-tumour heterogeneity: a looking glass for cancer? Nat Rev Cancer 2012, 12:323-334.

65. Gerlinger M, Rowan AJ, Horswell S, Larkin J, Endesfelder D, Gronroos E, Martinez P, Matthews N, Stewart A, Tarpey P, Varela I, Phillimore B, Begum S, McDonald NQ, Butler A, Jones D, Raine K, Latimer C, Santos CR, Nohadani M, Eklund AC, Spencer-Dene B, Clark G, Pickering L, Stamp G, Gore M, Szallasi Z, Downward J, Futreal PA, Swanton C: Intratumor heterogeneity and branched evolution revealed by multiregion sequencing. N Engl J Med 2012, 366:883-892.

66. Rini BI, Campbell SC, Escudier B: Renal cell carcinoma. Lancet 2009, 373:1119-1132.

\section{Pre-publication history}

The pre-publication history for this paper can be accessed here: http://www.biomedcentral.com/1741-7015/10/112/prepub

doi:10.1186/1741-7015-10-112

Cite this article as: Vasudev et al:: Renal cancer biomarkers: the promise of personalized care. BMC Medicine 2012 10:112.

\section{Submit your next manuscript to BioMed Central and take full advantage of:}

- Convenient online submission

- Thorough peer review

- No space constraints or color figure charges

- Immediate publication on acceptance

- Inclusion in PubMed, CAS, Scopus and Google Scholar

- Research which is freely available for redistribution

Submit your manuscript at www.biomedcentral.com/submit
Biomed Central 